\title{
The Place of Customary and Religious Laws and Practices in Ethiopia: A Critical Review of the Four Modern Constitutions
}

\section{Endalcachew Bayeh}

Ambo University, Department of Civics and Ethical Studies, College of Social Sciences and Humanities, Ambo, Ethiopia

\section{Email address:}

endbayeh@gmail.com

\section{To cite this article:}

Endalcachew Bayeh. The Place of Customary and Religious Laws and Practices in Ethiopia: A Critical Review of the Four Modern Constitutions. Social Sciences. Vol. 4, No. 4, 2015, pp. 90-93. doi: 10.11648/j.ss.20150404.14

\begin{abstract}
The objective of this paper is to examine the place of customary and religious laws and practices in the Ethiopian constitutions. To this end, the study made comparison as to the place of those elements in the four constitutions, thereby implying the changes and continuities. As a result, the study shows that the 1995 FDRE constitution better incorporated the customary and religious laws and practices as compared to other constitutions. The 1987 PDRE constitution is also relatively good compared to the 1931 and 1955 Imperial constitutions in terms of recognizing those elements in a way that can ensure equality of all sections of the society.
\end{abstract}

Keywords: Constitution, Custom, Ethiopia, Language, Religion

\section{Introduction}

The introduction of modern constitution in Ethiopia is a recent phenomenon. Until the early 1931 period, there was no constitution in Ethiopia in the modern sense. The leaders of the country had been exercising their power on the basis of customary and religious laws and practices (Miles, 2004). In other words, religious and customary laws and practices had been given a great importance. For instance, family relationships have been based on each community's religious and customary laws (ibid). The Ethiopian society is made up of large Christian and Muslim communities and some animists (like what is true for Nigeria albeit the percentage differs (Olusegun and Bodunde, 2014)) though they did not have equal political importance (Miles, 2004). In this regard, one can mention the place of Ethiopian Orthodox Church in the overall political practice of the pre-1931 period. The then leaders of Ethiopia were required to be the member as well as the defenders of Ethiopian Orthodox Church to maintain their legitimacy (Mohammed, 2011). Also, those who deviated from the laws of Ethiopian Orthodox Church suffered from great challenges (legitimacy crisis). Changes and continuities have been witnessed in the post-1931 period as regard to the attention given to religious and customary practices. In this paper, the focus is to review the four modern constitutions of Ethiopia based on how they recognized religious and customary laws and practices rather than their practical application on the ground. Hence, it intends to show how the consecutive legal frameworks of the country recognized customary and religious laws and practices. In the course of the analysis, the paper compares and contrasts the place of those elements in the four constitutions, thereby implying the changes and continuities. Accordingly, the culture, religion and language are made points of emphasis in the overall analysis.

\section{The Recognition of Religion}

The 1995 FDRE constitution guarantees the freedom of religion. So as to ensure religious freedom of citizens, the constitution clearly prohibits the interference of the government in the affairs of the religion under article 11 (3). Citizens can follow their own religion as there is no state religion which is imposed by the state (Art. 11(2)). In addition to conferring such freedom, the constitution guarantees equality of all religions as nobody shall be discriminated on the basis of his/her religious background (Art. 25).

Besides, Art. 27 (1) further states the fact that everyone has the freedom "to hold or to adopt a religion or belief of his choice, and the freedom, either individually or in community with others, and in public or private, to manifest his religion 
or belief in worship, observance, practice and teaching". Under sub Art.2 of the same article, believers are allowed to establish their own religious institutions to undertake religious activities. Therefore, the constitution provided significant freedom to follow and practice one's own religion.

Customary and religious laws are given some constitutional space to govern some affairs of the society. The most important provision which officially recognized customary and religious laws is Art.34. Accordingly, Art.34 (4) of the constitution provides recognition to marriage concluded based on religious and customary laws. And in fact, Art.1 (2) of the revised Ethiopian family law affirmed such a constitutional recognition. This shows the fact that citizens are allowed to conclude marriage based on their religious and cultural principles. These may vary from a religion to another and from one culture to another. Art. 34 (5) of the constitution also states that personal and family matters can be dealt with through religious and customary laws upon the consent of the parties. The consent of both parties should be secured personal and family matters to be judged by those laws. And, from the outset the issues should be concluded by religious or customary laws. In other words, once they are originally concluded on the basis of state laws, they cannot be subsequently resorted to religious and customary laws no matter whether the parties agree or not. Art. 78 (5) of the constitution also states that:

"Pursuant to sub-article 5 of article 34 the House of Peoples' Representatives and State Councils can establish or give official recognition to religious and customary courts. Religious and customary courts that had state recognition and functioned prior to the adoption of the constitution shall be organized on the basis of recognition accorded to them by this constitution".

Both Art. 34 and 78 in the constitution affirm an official recognition of the social pluralism in the Ethiopian society (Ayalew, 2012). These articles, therefore, imply that at least in those areas mentioned, religious and customary laws and courts are allowed to function separately from, and parallel with the state-sponsored legal-judicial system. Generally, it can be deduced from the above discussion that, the 1995 FDRE constitution recognizes not only religious freedom but also the application of religious laws and practices in some affairs of the society.

The 1987 PDRE constitution, under Art.46 (1), also guarantees freedom of religion. Besides, the constitution clearly outlines that state and religion are separate (Art. 41(3)) in the sense that one cannot interfere in the affairs of the other. After all, it is under this constitution that Ethiopia has come to be a secular state for the first time. Thus, citizens were free to practice their own religion so long as it does not contravene with the interest of the state and the revolution, public morality, and the freedom of other citizens (Art. 41(3)). Besides, the preamble of the constitution preaches equality of religion in the country. Thus, one's religion cannot be taken to be more important than and/or superior to others' religion. The second largest religion in the country, Islam, has got recognition in a new secular state like all other religions
(Abbink, 2014). It was also true that with the collapse of the imperial system Ethiopian Orthodox Church was reduced to a mere religious organization with a very little political significance (Miles, 2004).

Thus, what the 1995 and 1987 constitutions have in common is, inter alia, the principle of secularism. In both cases, state and religion are separated so that one cannot interfere in the affairs of the other. Also, citizens are free to follow and practice their own religion. All religions are equally recognized.

However, in the 1931 constitution, Ethiopia was a theocratic state where state and religion were fused together. The same holds true for the 1955 revised constitution as Ethiopia was a theocratic state. The preamble of this constitution clearly put Emperor Haile Selassie as an elect of God. More importantly, the constitution provides the monarch with a divine power to rule his subjects. If one read carefully the preamble of the constitution, he/she will understand the fact that the constitution provides utmost significance for religious precepts. One best example in this regard is Art.7 which requires the coronation of the emperor to be held in accordance with the previsions and laws determined by Ethiopian Orthodox Church. The constitution is tailored to fit Ethiopian Orthodox Church. If one goes through, inter alia, Articles 16, 20, 21, and 23, he/she will understand the extent of incorporation of religious elements into the constitution and how the state is committed to defend Ethiopian Orthodox Church. Consequently, one can deduce that the Ethiopian Orthodox Church had the central place in the 1955 revised constitution in particular and the political system of the country in general.

Broadly speaking, state and religion were intermingled under the Imperial regime. It is worth mentioning here that, recognition was given only to Ethiopian Orthodox Church. The idea is underscored by Art.126 of the constitution that the Ethiopian Orthodox Church is the established church of the Empire and is supported by the state. Most importantly, the same article states that the emperor is to profess the orthodox faith. On the contrary, other religions were not recognized and there was no freedom to follow other faiths. For instance, to hold any political position one has to be a member and a defender of Ethiopian Orthodox Church. Therefore, though Art.40 of the revised constitution guarantees non-interference in the exercise of the rites of any religion by residents of the empire, the prevailing condition was not conducive to do so for non-Orthodox believers. In other words, the prevailing environ was not favorable to believers of other religions, thereby constraining the principle of religious freedom in the country. In fact, it is asserted that Emperor Haile Selassie's rule was criticized for treating Muslims in Ethiopia as "second class citizens" because of their religious affiliation (Miles, 2004, Mohammed, 2011).

\section{The Recognition of Language}

Article 5 of the Federal Democratic Republic of Ethiopia 
constitution stipulates equal state recognition of all languages that found in Ethiopia. Most importantly, it allows all members of Ethiopian federation to use their own respective language as a working language. Article 39 also stipulates the unconditional right to self-determination of every Nation, Nationality and People in Ethiopia. Accordingly, every Nation, Nationality and People in Ethiopia has the right to speak, to write and to develop its own language (Art.38 (2)). From this article one can conclude the utmost significance given to the flourishing of the languages of each nations and nationalities. Therefore, all Ethiopian Nations and Nationalities are allowed to develop their own language.

The 1987 constitution, under Art.2 (5), also clearly guarantees equality of Ethiopian languages. The languages of the nationalities are given with an equal treatment, respect and development. Therefore, Ethiopian nationalities were free to use and develop their own language. Though the extent differs, the equal recognition given for Ethiopian languages is what the 1995 and 1987 constitutions have in common.

The 1931 constitution is silent as to the recognition of the languages of the state. However, as Ethiopia was a theocratic state and a follower of the Ethiopian Orthodox Church, the language used was Amharic. The languages of nations and nationalities were not given a due recognition. The same holds true for the 1955 revised constitution of Ethiopia. It only states under Art.125 that Amharic is the official language of the country while it was silent on the recognition of other languages. Thus, it was only Amharic language which obtained official recognition among many languages of the state.

\section{The Recognition of Culture of Nations and Nationalities}

Culture has a significant role in the overall development of a given country (Yabo, 2015). The preamble of the 1995 FDRE constitution promised to maintain the country's rich and proud cultural legacies. As outlined in Art.39 (2) "Every Nation, Nationality and People in Ethiopia has the right to express, to develop and to promote its culture; and to preserve its history". In addition, Art. 41 (9) imposes responsibility on the State to protect and preserve historical and cultural heritages. Hence, one can deduce that the cultures of Ethiopian nations and nationalities are given a due recognition and protection.

The equity among nationalities and their right to selfdetermination are guaranteed in the preamble of the 1987 constitution. Thus, by implication, one may understand the recognition given to the nationalities to develop and promote their respective cultures. Equal participation in cultural affairs is promised to all citizens of Ethiopia (Art. 35). Thus, one can infer some common points between the 1995 and 1987 constitutions. However, the 1995 FDRE constitution provides a very clear recognition of the cultures of nationalities
The 1931 and 1955 constitutions have stated nothing about the recognition of the cultures of the nationalities as the issue was not given a considerable emphasis. The two constitutions kept silent on the issue under question. Thus, this fact makes the two constitutions different from the 1995 and 1987 constitutions. However, one can infer from the prevailing system the place give to the culture of Amhara ethnic group.

\section{Pluralism}

The 1995 FDRE constitution establishes an ethnolinguistic federalism. Article 39 stipulates the unconditional right to self-determination of every Nation, Nationality and People in Ethiopia. This mean that, each group is allowed to govern itself (Art.39 (3)) by maintaining its identity. This underscores the idea that the 1995 constitution accepts pluralism. It tries to accommodate diversity while maintaining the purpose of unity. Moreover, the preamble of the constitution begins with the following statement "We, the Nations, Nationalities and Peoples of Ethiopia...." thereby recognizing that Ethiopia is the nation of nations. In other words, it recognizes the existence of diverse nations and nationalities with their diverse backgrounds. Ultimately, it tries to maintain a peaceful coexistence of diverse nationalities through federalism.

The 1987 PDRE constitution also expresses, in its preamble, the equality of nationalities and their right to selfdetermination. The equity among all nationalities is also affirmed under Art.2 (1). Besides, Art.2 (2) guarantees equalities of nationalities through combating chauvinism and narrow minded nationalism. Moreover, the constitution guarantees autonomous regions (Art.2 (4)). These issues show the fact that there was recognition to the prevalence of different nationalities which makes the 1987 constitution similar to the 1995 constitution. However, no emphasis was put on the issue of nationalities as compared to the 1995 FDRE constitution since the issue, in the former, was the unity of the country as the motto shows "Ethiopia First".

However, the 1931 and 1955 constitutions are totally silent towards the issue of nationalities. No single provision was stated in any of the constitutions to deal with the rights and equality of nationalities. Therefore, it can be inferred that both constitutions failed to recognize the existence of various nationalities thereby leaving no room for pluralism. Both constitutions of the Imperil regime were centered on consolidating political and legal centralization. Most importantly, under the Imperial regime, the system favored one ethnic group, Amhara. Thus, it disregarded the existence of diverse nations and nationalities (Alemseged, 2004 \& Aregawi, 2004).

\section{Conclusion}

From the above discussion, it is apparent that customary and religious laws and practices have been incorporated, in one way or another, into the four modern constitutions of Ethiopia. It is also clear that the degree of incorporation of 
religious and cultural elements varies from one constitution to the other. The 1995 FDRE constitution is better in terms of equally recognizing the cultures, religions, and languages of society.

\section{Laws}

The 1931 Constitution of the Empire of Ethiopia

The 1955 Revised Constitution of the Empire of Ethiopia

The 1987 Constitution of People's Democratic Republic of Ethiopia

The 1995 Constitution of Federal Democratic Republic of Ethiopia

The Revised Family Code of Federal Democratic Republic of Ethiopia, Proclamation No. 213/2000

\section{References}

[1] Abbink, Jon (2014) Religious Freedom and the Political Order: The Ethiopian 'Secular State' and the Containment of Muslim Identity Politics, Journal of Eastern African Studies, 8 (3): 346-365.
[2] Alemseged Abbay (2004) Diversity and State Building in Ethiopia, African Affairs, 103 (413): 593-614.

[3] Aregawi Berhe (2004) The Origins of the Tigray People's Liberation Front, African Affairs, 103 (413): 569-592.

[4] Ayalew Getachew (2012) Customary Laws in Ethiopia: A Need for Better Recognition? Working Paper, Copenhagen: Danish Institute for Human Rights.

[5] Miles, John (2004) Customary and Islamic Law and its Development in Africa, Law for Development Review, pp.100154.

[6] Mohammed Abdo (2011) Legal Pluralism, Sharia Courts, and Constitutional Issues in Ethiopia, MIZAN LAW REVIEW, 5 (1): 72-104.

[7] Olusegun Ajayi, Bodunde Oluwafemi (2014) Religious Practices and National Development, Social Sciences, 3 (4): $105-111$.

[8] Yabo Li. (2015) Cultural Identity in Intercultural Communication, Social Sciences, 4 (2): 23-26. 